\title{
多自由度ロボットにおける機構自由度の縮退を利用した アクチュエータの選択的利用
}

\author{
琴 坂 信 哉* 大 滝 英 征*

\section{Selective Utilization of Actuator for a Humanoid Robot by Singular Configuration}

\author{
Shinya Kotosaka* and Hideyuki Ohtaki*
}

\begin{abstract}
In general, robot should not be operated while it is in a singular configuration since operation degenerates its degrees of freedom. However, humanoid robots are capable of performing tasks while in a state of singular configuration because humanoid robots have many degrees of freedom. In this paper, new task method is proposed for humanoid robots, featuring selective utilization of their actuators while in the singular configuration. First, we define the effective singular configuration for a task and introduce a classification for joints. Next, we propose a method to identify the joint as effectively having a singular configuration. Finally, we demonstrate physical simulation results that include leading a robot in the singular configuration through the task. The advantages of the proposed method are that it supports economizing the robot's energy consumption and applies more power to the hand.
\end{abstract}

Key Words: Humanoid Robot, Singular Configuration, Redundant Manipulator, Trajectory Generation

\section{1. は じめに}

近年, ヒューマノイドロボットに代表されるような数十自由 度を持つ多自由度ロボットが実現可能になってきた [1]〜 [4]. ま た，これらのロボットを有効に活用するための運動制御，運動 軌道生成手法の研究が行われている [5] [6]. しかし, 多数ある 自由度は，作業内容に応じて分割されて用いられることが多い。 例えば, 下半身の自由度は歩行に, 腕は手先による作業にと特 化して用いられることが多い，そのため, 自由度の利用という 観点から見ると, 従来のロボットマニピュレータと変わりがな く, 多自由度であることを積極的に活用しているとは言えない のが現状である。 また，これらの多自由度ロボットは，人間が 行っているような作業を行わせるには, まだ手先発生力が不十 分であることや，独立したエネルギー供給源のみしか利用でき ない場合には, 稼働時間が短いなどの問題点がある. 本研究で は，これらの問題点を解決するために, 多自由度ロボットにお いて関節機構の縮退を用いたアクチユエータの選択的利用を提 案する.

\section{2.これまでの多自由度ロボットの運動軌道生成に 関する関連研究}

これまでヒューマノイドロボットにおける運動軌道生成に関す る研究では, 主に歩行運動生成が注目を集めてきた $[7] 〜[9]$. 最

原稿受付 2006 年 10 月 3 日

*埼玉大学

*Saitama University
近では, 多数の自由度を活用して安定な作業姿勢を維持するため の手法 [10] [11] などが提案されるようになってきた。しかし，こ れらは関節の縮退状態を考慮した手法ではない，また，人間の運 動を観測することにより，多自由度ロボット（特にヒューマノイ ドロボット）の運動軌道生成を行おうとする研究もある [12] [13]. これらの研究では, 関節レベルで運動軌道を生成していること が多く，ロボットの関節が縮退することも許容している．しか し，これらは関節の縮退状態を作業に用いようとするものでは ない.

またこれまでのロボット工学における縮退に関する研究は, 主に縮退状態を回避するための運動生成手法や縮退状態付近で も手先の軌道制御を可能にするための手法の開発であった。例え ば, 圥長自由度を活用した障害物回避運動軌道計画や縮退状態を 許容することのできる運動制御 [14] [15], 近年では縮退状態のコ ンフィグレーションを考慮した運動軌道生成手法の提案 [16] [17] など多数の研究がある。しかし，これらも関節の縮退状態の特 性を積極的に作業実行に用いる手法ではない，他に多自由度口 ボットの運動軌道生成で縮退を考慮した研究としては, 山根ら の研究 [18] がある. この研究は, 縮退状態になることを許容し つつ運動軌道生成を可能とした研究であるが, 主眼は多様な運 動軌道生成におかれており関節縮退を作業に活用することを提 案しているわけではない.また，縮退状態におけるロボットの機 構特性についての研究も行われているが, 一部の研究者によっ てのみ研究が行われているのが現状である [19]〜 [22].

そのほかにも, 多数の自由度を持った超午長自由度機構の運 動制御に関する研究も行われてきている. 古くは, Salisburyの 
研究に始まり [23], 多数の研究者が逆運動学解法の研究 [24], 目 的形状への形状制御方法 [25] [26] の研究等が行われてきた。 こ れらも運動軌道生成, 運動制御方法の提案であって, 縮退を用 いた作業方法の提案ではなかった。

\section{3. 多自由度ロボットにおける関節自由度の縮退を 用いた作業方法の提案}

人間が行う日常的な動作の中には, 时をのばして押し動作を 行ったり，足を伸ばした状態で立位姿勢を維持したりといった 動作が多く見受けられる．例えば，Fig. 1 のように，手のひら で押し動作を行う場合，手首関節，时関節を縮退させることに より，出力の小さな手首関節や肘関節に大きな負荷トルクを発 生させることなく, 体幹部の大きな出力を持つ筋肉を用いて手 先力を発生させている. 縮退している関節部では, 関節負荷を 関節の機構で支えているため，筋肉に大きな負担をかけること がない.このような関節自由度の縮退を用いたアクチュエー夕 の選択的利用は, 多自由度ロボットシステムにおいてロボット システムの持つ能力を最大限に活用するために非常に有用であ ると考えられる.

一般に, 関節自由度の縮退は, 逆運動学計算が不能になる, 手先の運動自由度が減少するなどの問題を引き起こすことから, ロボットの動作には積極的には用いられてこなかった。しかし， 非常に多くの自由度を持つロボットでは, 一部の関節が縮退し たとしても，手先もしくは足先の運動自由度が減少するとは限 らない.すなわち, 一部の関節の縮退により関節自由度が減少 したとしても，全体の動作は他の関節を駆動することにより続 行できる場合が多いと考えられる.

以上により，本研究では，作業方向への関節縮退を利用した アクチュエータの選択的利用による作業方法を提案する. 本手 法では，ロボットのリンク機構の自由度を積極的に縮退させる ことにより，負荷トルクを負担するアクチュエータを選択する. 例えば，出力の小さな関節を縮退させ，出力の大きな関節によ

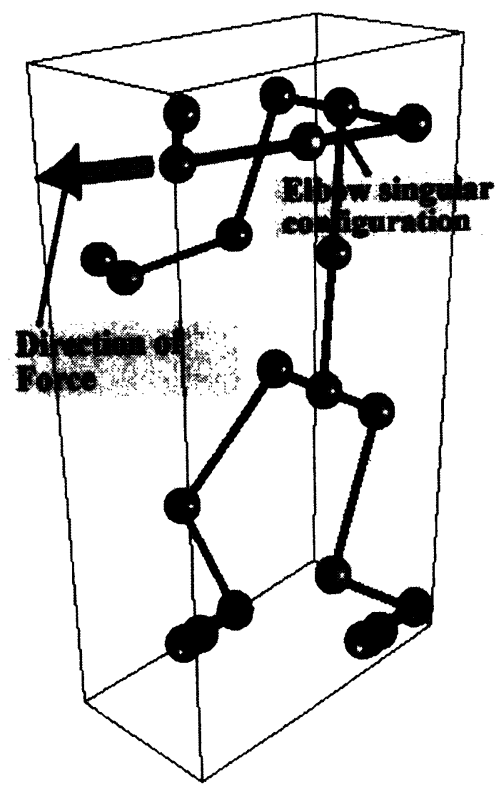

Fig. 1 Pushing task with singular configuration
り手先出力を発生させるなどの使い方が考えられる. Fig. 2 に 関節縮退を用いてアクチュエータの選択的利用を行った場合の 模式図を示す。図では, 手首関節, 时関節を縮退させることに より，それらの関節に大きな負荷をかけることなく体幹部の大 出力のアクチュエータを用いて大きな手先押しつけ力を発生さ せている．通常のひじを曲げたような姿勢で作業を行う場合に は, 手首および时関節の出力トルクが飽和することがないよう に手先押しつけ力を制限することが必要である。しかし，両関 節を縮退させれば, 手首関節, 时関節の出力飽和を考慮するこ となく, 手先押しつけ力を体幹部のアクチュエータで発生させ ることができる，このとき，体幹部のアクチュエータ出力が十 分に大きければ，従来方法よりも，大きな手先押しつけ力を発 生させることができる，すなわち，本手法を用いることにより， 多自由度ロボットにおいて出力の小さな関節を考慮せず手先で 大きな力を発生したり，縮退させた関節負荷の低減化により消 費エネルギーを低減化できる可能性がある。

なお, 本研究で提案する手法は, ヒューマノイドロボットに 代表されるような分岐構造を持つ多リンク, 多自由度構成のロ ボットを対象とする.すなわち, 出力の異なるアクチュエータ や，異なるリンク長を持つ複数のリンク機構から構成されてい るロボットを対象とする。これらのロボットでは, 通常, 体幹部 に相当する部分に, 大出力のアクチュエータを配置しているこ とが多い.このようなロボットでは, 作業方向への関節縮退を 用いたアクチュエータの選択的利用法が有効であると考えられ る.よって, 本手法では, 同じリンク長, 同じアクチュエータか ら構成されているような蛇型, 超圥長マニピュレータのような 構造のロボットは対象としない. もちろん, これらのロボット でも同様に関節自由度の選択的利用は可能ではあるが, 上記の ように手先出力の増加や関節負荷の低隇化が期待できない. 例 えば，手先負荷を負担するアクチュエー夕を縮退させても，同 じ出力の別のアクチュエータに負担させるしかない場合は, 手 先出力の増加が実現できない. そのため, 本手法が有効ではな いからである。

4 章では, アクチュエータの選択的利用を行うための縮退可 能関節の抽出方法ついて述べる. 実際に 2 種類の機構に関し

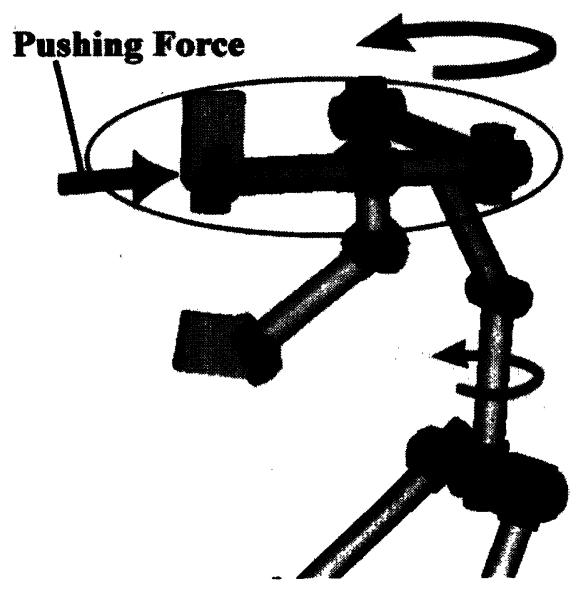

Fig. 2 Selective utilization of actuator by singular configuration 
て, 縮退可能関節の抽出を行う. 5 章では, 関節縮退によるア クチュエータの選択的利用の有効性をシミュレーションにより 確認する.

\section{4. 縮退させる関節の選択手法}

\section{1 関節自由度の縮退を用いた作業方法に有効な関節縮退}

多自由度ロボットでは, 縮退を発生する関節の組み合わせは 無数に存在する。また，その縮退の形態も様々である。しかし， そのすべてが前章で提案した縮退を利用した動作に有効に働く わけではない，例えば，Fig. 2 に示した縮退姿勢において，図 中に矢印で示した方向から力を受ける場合には，縮退を用いた 動作は有効に㗢く，それに対し，矢印で示した方向に直交する 方向から力を受けた場合には，関節を縮退させることの利点は 失われてしまう．また，Fig. 3 (a) にあるような姿勢では，重力 による負荷の方向と縮退の方向がまったく一致しないため，負 荷トルクは低減化されない. また, Fig. 3(b) の姿勢では, 自由 度の縮退が離れたリンク間で発生しているため, 構造で外力を 支えることができないため，縮退を用いることは有効ではない， これらを考慮して, 本研究では有効な関節自由度の縮退を次の ように定義する。

\section{縮退を用いた作業方法に有効な関節自由度の縮退の定義}

ロボットの効果器で発生すべき力（モーメント力は含まな い）の方向と縮退した関節を含む連続したリンクの方向べク トルが一致するような関節縮退.

\section{2 関節機構の分類}

有効な関節縮退を用いたアクチュエータの選択的利用法を作 業計画，運動軌道計画に活用するためには，どの関節がどのよ うな関節角度のときに「有効な縮退」を起こすかを網羅的に調 ベる必要がある，そのような情報があれば，例えば，縮退をさ せたい関節の角度を縮退状態で固定し, 他の関節を用いて運動 軌道計画を行うことによって，アクチュエータの選択的利用が

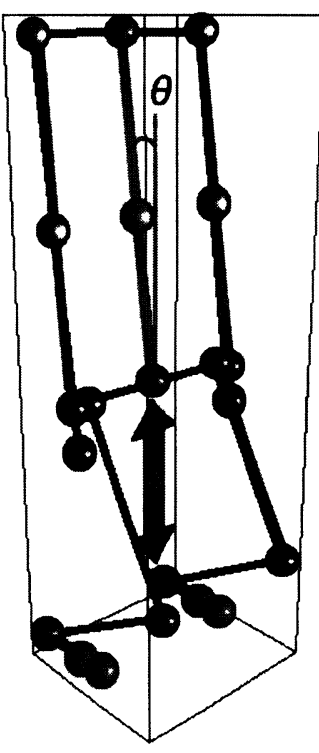

(a)

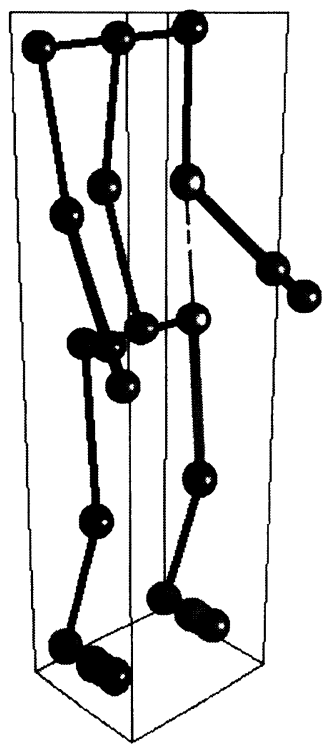

(b)
Fig. 3 Ineffective singular configuration
可能になる.そこで，まず次のような仮定をおき関節機構の分 類を行う.

仮定 1：それぞれの関節は，1 自由度の回転対偶関節を持つ ものとする。

仮定 2 ：関節間のオフセットは，各座標軸方向にのみ存在す るとする。

仮定 3 ：関節間のねじれ角は，0 $[\mathrm{deg}]$ もしくは $\pm 90[\mathrm{deg}]$ と する。

以上のように仮定すると, 関節の種類は Fig. 4 にある 4 種類 に分類される.

\section{3 リンク間のカとモーメント伝達関係の導出}

二つのリンクが一つの関節で接続されているときに，何らか の力もしくは，モーメント力が片方のリンクに加わったときに， もう一方のリンクにどのような力もしくはモーメントカが伝達 されるのか, 関節にどのような負荷トルクが発生するのかを導 出した。ここでは，リンクが剛体であることを仮定する.

Fig. 4 のように, 入力側リンク $\left(\mathrm{X}_{\mathrm{in}}, \mathrm{Y}_{\mathrm{in}} \ldots\right)$, 出力側リンク $\left(\mathrm{X}_{\text {out }}, \mathrm{Y}_{\text {out }} . ..\right)$ を仮定すると, 入力側リンクの各座標軸方向 に力もしくはモーメントカが㗢くとすると, Fig. 4 に示した関 節の種類により，次のように伝達されることが分かる。

(1) $\mathrm{F}$ 型関節の力伝達関係

F 型関節の力伝達関係を Table 1 (a) に示す. Table 1 (a) で は, 入力側リンクの各座標軸方向ごとに, 関節に負荷トルクが 発生するかどうか, 出力側リンクに力もしくはモーメントカが 伝達されるかどうかが示されている．関節角度（リンク間の相 対角度）に依存する場合は，その角度範囲を示した。 Fx, Fy， $\mathrm{Fz}$ は，Fig. 4 にある各座標軸方向の力を表し, $\mathrm{Mx}, \mathrm{My}, \mathrm{Mz}$ は, 各座標軸周りのモーメント力を表す。表中, 出力側リンク

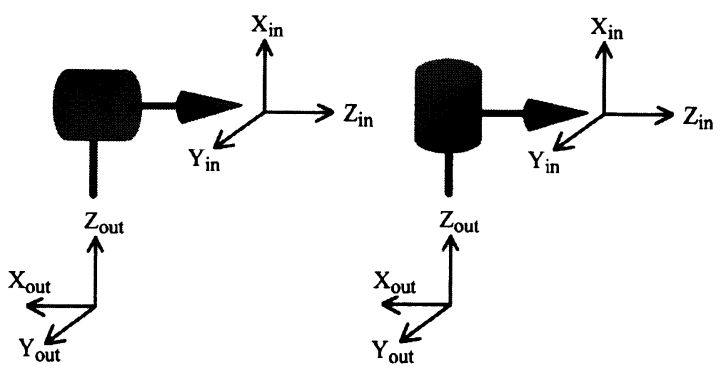

(a) F type joint

(b) T type joint

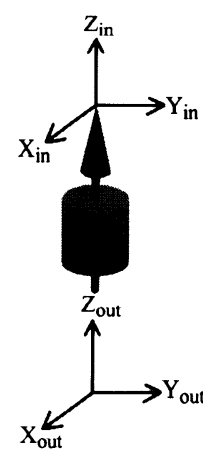

(c) R type joint

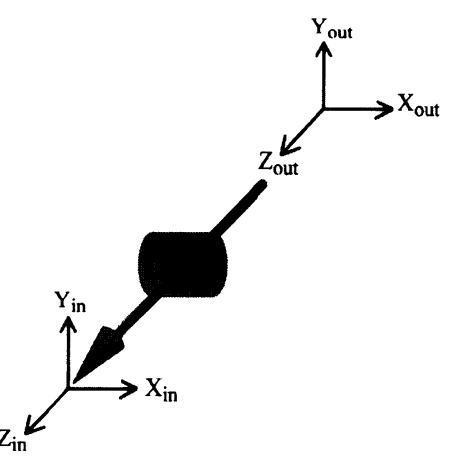

(d) P type joint
Fig. 4 Classification of joints 
Table 1 Classification of force transmission for each type of joint

(a) F type joint

\begin{tabular}{|c|c|c|c|c|c|c|c|c|c|c|c|c|c|c|}
\hline \multirow[b]{3}{*}{ Input link } & \multirow[b]{3}{*}{ moment of force } & \multirow{2}{*}{\multicolumn{12}{|c|}{\begin{tabular}{|l} 
Output link \\
joint angle non-depended
\end{tabular}}} & \multirow{3}{*}{ notes } \\
\hline & & & & & & & & & & & & & & \\
\hline & & Fx & Fy & $\mathbf{F z}$ & $M x$ & My & $\mathbf{M z}$ & Fx & Fy & $\mathrm{Fz}$ & $\mathrm{Mx}$ & My & $\mathrm{Mz}$ & \\
\hline $\mathrm{Fx}$ & nothing & 0 & - & 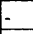 & 0 & - & - & - & $\theta \neq 0, \pi$ & $\theta \neq \pi / 2$ & - & $\theta \neq \mathbf{0}, \pi$ & $\theta \neq \pi / 2$ & \\
\hline Fy & nothing & 0 & - & - & 0 & - & - & - & $\theta \neq \pi / 2$ & $\theta \neq 0, \pi$ & . & $\theta \neq \pi / 2$ & $\theta \neq \mathbf{0}, \boldsymbol{\pi}$ & \\
\hline $\mathbf{F z}$ & nothing & all & 0 & 0 & 0 & all & 0 & & & & - & & & \\
\hline Mx & noching & - & - & - & 0 & - & - & $\theta \neq 0, \pi$ & $\theta \neq \pi / 2$ & $\theta \neq 0, \pi$ & - & $\theta \neq 0, \pi$ & $\theta \neq \pi / 2$ & \\
\hline My & nothing & $E$ & - & $E$ & 0 & - & - & $\theta \neq \pi / 2$ & $\theta \neq 0, \pi$ & $\theta \neq \pi / 2$ & - & $\theta \neq \pi / 2$ & $\theta \neq 0, \pi$ & \\
\hline $\mathrm{Mz}$ & always exist & 0 & all & 0 & all & 0 & 0 & & & & F. & & - & \\
\hline
\end{tabular}

(b) $\mathrm{T}$ type joint

\begin{tabular}{|c|c|c|c|c|c|c|c|c|c|c|c|c|c|c|}
\hline \multirow[b]{3}{*}{ Input link } & \multirow[b]{3}{*}{ moment of force } & \multicolumn{12}{|c|}{ Output link } & \multirow{3}{*}{ notes } \\
\hline & & \multicolumn{6}{|c|}{ joint angle non-depended } & \multicolumn{6}{|c|}{ joint angle depended } & \\
\hline & & Fx & Fy & $\mathrm{Fz}$ & $\mathbf{M x}$ & My & $\mathrm{Mz}$ & $\mathbf{F x}$ & Fy & $\mathrm{Fz}$ & $\mathrm{Mx}$ & My & $\mathbf{M z}$ & \\
\hline Fx & nothing & 0 & 0 & all & - & - & 0 & - & - & - & $\theta \neq 0, \pi$ & $\theta \neq \pi / 2$ & - & \\
\hline Fy & always exist & - & - & 0 & 0 & 0 & all & $\theta \neq 0, \pi$ & $\theta \neq \pi / 2$ & - & - & - & - & \\
\hline Fz & nothing & - & - & 0 & - & - & 0 & $\theta \neq \pi / 2$ & $\theta \neq 0, \pi$ & - & $\theta \neq 0, \pi$ & $\theta \neq \pi / 2$ & - & \\
\hline Mx & always exist & - & - & 0 & 0 & 0 & all & $\theta \neq 0, \pi$ & $\theta \neq \pi / 2$ & - & - & - & - & \\
\hline My & nothing & - & - & 0 & - & - & 0 & $\theta \neq \pi / 2$ & $\theta \neq 0, \pi$ & - & $\theta \neq 0, \pi$ & $\theta \neq \pi / 2$ & - & \\
\hline Mz & nothing & - & - & 0 & - & - & 0 & $\theta \neq 0, \pi$ & $\theta \neq \pi / 2$ & - & $\theta \neq \pi / 2$ & $\theta \neq 0, \pi$ & - & \\
\hline
\end{tabular}

(c) R type joint

\begin{tabular}{|c|c|c|c|c|c|c|c|c|c|c|c|c|c|c|}
\hline \multirow[b]{2}{*}{ Input link } & \multirow[b]{2}{*}{ moment of force } & \multicolumn{12}{|c|}{\begin{tabular}{|l|} 
Output link \\
joint angle non-depended \\
\end{tabular}} & \multirow{2}{*}{ notes } \\
\hline & & $\overline{F x}$ & Fy & $\mathbf{F z}$ & $\mathbf{M x}$ & My & $\overline{M z}$ & $\overline{F x}$ & Fy & Fz & $\mathbf{M x}$ & My & $\mathbf{M z}$ & \\
\hline Fx & nothing & - & - & 0 & - & - & 0 & $\theta \neq \pi / 2$ & $\theta \neq 0, \pi$ & - & $\theta \neq 0, \pi$ & $\theta \neq \pi / 2$ & - & \\
\hline Fy & nothing & - & - & 0 & - & - & 0 & $\theta \neq 0, \pi$ & $\theta \neq \pi / 2$ & - & $\theta \neq \pi / 2$ & $\theta \neq 0, \pi$ & - & \\
\hline $\mathbf{F z}$ & nothing & 0 & 0 & all & 0 & 0 & 0 & - & - & - & - & - & - & \\
\hline Mx & nothing & 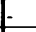 & - & 0 & - & - & 0 & $\theta \neq 0, \pi$ & $\theta \neq \pi / 2$ & - & $\theta \neq \pi / 2$ & $\theta \neq 0, \pi$ & - & \\
\hline My & nothing & - & - & 0 & - & - & 0 & $\theta \neq \pi / 2$ & $\theta \neq 0, \pi$ & - & $\theta \neq 0, \pi$ & $\theta \neq \pi / 2$ & - & \\
\hline $\mathrm{Mz}$ & always exist & 0 & 0 & 0 & 0 & 0 & all & - & - & - & - & - & I. & \\
\hline
\end{tabular}

(d) P type joint

\begin{tabular}{|c|c|c|c|c|c|c|c|c|c|c|c|c|c|c|}
\hline \multirow[b]{3}{*}{ Input link } & \multirow[b]{3}{*}{ moment of force } & \multirow{2}{*}{\multicolumn{12}{|c|}{\begin{tabular}{|l|} 
Output link \\
joint angle non-depended \\
\end{tabular}}} & \multirow{3}{*}{ notes } \\
\hline & & & & & & & & & & & & & & \\
\hline & & $\mathbf{F x}$ & Fy & $\mathbf{F z}$ & Mx & My & $\mathbf{M z}$ & Fx & Fy & $\mathbf{F z}$ & $\mathbf{M x}$ & My & Mz & \\
\hline $\mathbf{F x}$ & nothing & all & 0 & 0 & 0 & - & - & - & - & - & - & $\theta \neq \pi$ & $\theta \neq 0, \pi$ & $\mathrm{My}, \mathrm{Mz}$ : if the length of moment arm is same. \\
\hline Fy & always exist & 0 & - & - & - & 0 & 0 & - & $\theta \neq \pi / 2$ & $\theta \neq 0, \pi$ & $\theta \neq \pi$ & - & - & Mx : if the length of moment arm is same. \\
\hline $\mathbf{F z}$ & depends on the ande & 0 & - & - & - & 0 & 0 & - & $\theta \neq 0, \pi$ & $\theta \neq \pi / 2$ & $\theta \neq 0, \pi$ & - & - & Under degenerated condition, Fy and $\mathrm{Mx}=0$ \\
\hline $\mathbf{M x}$ & always exist & 0 & 0 & - & all & 0 & 0 & - & - & $\theta \neq 0, \pi$ & - & - & - & Fy: if the length of moment arm is same. \\
\hline My & nothing & - & 0 & 0 & 0 & - & - & $\theta \neq \pi$ & - & - & - & $\theta \neq \pi / 2$ & $\theta \neq 0, \pi$ & Fx : if the length of moment arm is same. \\
\hline $\mathbf{M z}$ & nothing & - & 0 & 0 & 0 & - & - & $\theta \neq 0, \pi$ & - & - & - & $\theta \neq 0, \pi$ & $\theta \neq \pi / 2$ & $\mathrm{Fx}, \mathrm{My}(\theta \neq \pi)$ : if the length of moment arm is same. \\
\hline
\end{tabular}

“joint angle non-depended” の列で，“0”と書かれた部分は, 入力側の力もしくはモーメントカそれぞれを伝達しないことを 表しており，また“-”は，関節角に依存して力もしくはモーメ ントカが伝達されることを示している. “all”と書かれている部 分は, 関節角に依存せずに力もしくはモーメント力が伝達され ることを示している. “joint angle depended”の列では, “-” が伝達されないことを, または伝達される場合の関節角 $\theta$ の条 件を記入してある.なお, 入力和が出力側のリンクの座標系の 関係は, Fig. 4 に示す通りである. また, 関節角 $\theta$ は, Fig. 4 に 示した状態を 0 度として定義している.

$\mathrm{F}$ 型関節では, 入力側リンクの $\mathrm{Z}$ 軸周りのモーメントカ $: \mathrm{Mz}$ が加わった場合，関節角に依存せずに関節負荷トルクが発生す る. それ以外では, 関節に負荷トルクは発生しない. また, 入力 側 Fx 方向に力が加わった場合, 出力側リンクの Fx 方向, $\mathrm{Mx}$ 方向には力, モーメント力は伝達されない. そして, Fy, Fz 方 向, $\mathrm{My}, \mathrm{Mz}$ 方向には関節角に依存して伝達が行われる. 入力 リンクの Fz 方向に力が加わった場合には, 出力側リンクの Fx 方向もしくは $\mathrm{My}$ 方向に常に力もしくはモーメントカとして伝
達される. 入力側 $\mathrm{Mz}$ 方向のモーメント力は, 出力側 $\mathrm{Mx}$ 方向 のモーメントカとして伝達される.

また，以上のことから， $\mathrm{F}$ 型関節は本研究で定義するところ の有効な縮退を起こさないことが分かる.この特徴は, 次に述 ベる $\mathrm{T}$ 型関節でも同様で，オフセットを持つ関節は有効な縮退 を発生しない.

\section{(2) $\mathrm{T}$ 型関節の力伝達関係}

同様に, $\mathrm{T}$ 型関節の力伝達関係を Table $1(\mathrm{~b})$ に示す. Table 1 (a) と同様に, $\mathrm{T}$ 型関節の場合には, 入力側リンクの $\mathrm{y}$ 軸 方向に力：Fy が加わった場合，および入力側リンクの $\mathrm{Z}$ 軸周 りのモーメントカ：Mzが加わった場合に関節角に依存せずに 関節負荷トルクが発生する，それ以外では，関節に負荷トルク は発生しない. また，入力側リンクに加わる力，モーメントカ は, Table 1 (b) に示したように出力側リンクに伝達される.

先に述べたように， $\mathrm{T}$ 型関節では有効な縮退を発生しない.

(3) $\mathrm{R}$ 型関節の力伝達関係

次に, $\mathrm{R}$ 型関節の力伝達関係を Table $1(\mathrm{c})$ に示す. $\mathrm{R}$ 型関節 の場合には, 入力側リンクの $\mathrm{Z}$ 軸周りのモーメントカ $: \mathrm{Mz}$ が 
加わった場合に，関節角に依存せずに関節負荷トルクが発生す る。それ以外では，関節に負荷トルクは発生しない。また，入 カ側リンクに加わる力, モーメント力は, Table 1 (c) に示した ように出力側リンクに伝達される.

$\mathrm{R}$ 型関節でも同様に有効な縮退を発生しない.

(4) $\mathrm{P}$ 型関節の力伝達関係

最後に $\mathrm{P}$ 型関節の力伝達関係を Table $1(\mathrm{~d})$ に示す. $\mathrm{P}$ 型関 節の場合には，入力側リンクの $\mathrm{y}$ 軸方向に力：Fy が加わった 場合，および入力側リンクの $\mathrm{Z}$ 軸周りのモーメントカ： $\mathrm{Mx}$ が 加わった場合に関節角に依存せずに関節負荷トルクが発生する. また，入力側リンクに加わる力，モーメントカは, Table 1 (d) に示したように出力側リンクに伝達される.

$\mathrm{P}$ 型関節で特徴的なのは，入力側リンクの $\mathrm{z}$ 軸方向に力 $: \mathrm{Fz}$ が加わった場合に，関節角に依存した関節負荷トルクが発生す る点である。この関節は，4.1節で定義した有効な縮退を発生 する関節である，この種類の関節では，縮退を発生させること により手先に力が加わっていたとしても関節に負荷トルクを発 生させないことが可能となる.

\section{4 力伝達関係を用いた縮退可能関節の探索方法}

縮退可能な関節の探索は, 4.3 節で求めた力伝達関係を用い て，押しつけ力等を発生させる手先から順に次のリンクにどの ような力が伝達されるかを調べることによって行う。

まず, 手先に加わる力のべクトルから, 力伝達関係の表から 関節負荷トルクが発生するかどうかを調べる. 関節負荷トルク が発生しない場合には, 表から次のリンクへ伝達される力, モー メントカを調べる. 次のリンクへ伝達される力, モーメントカ から, 同様に次のリンクで関節負荷トルクが発生するか, さら に次のリンクに伝達される力，モーメントカを調査する。これ を繰り返すことにより，関節に負荷トルクが発生するかどうか を調べていく．この探索の途中で，関節角に依存して関節負荷 トルクが発生する関節（基本的に $\mathrm{P}$ 型関節）があった場合には, そこが縮退可能関節であることになる。もし，探索の過程で関 節角に依存せずに負荷トルクが発生する関節があった場合には, その関節で負荷を必ず受ける必要がある。この探索は, 最終的 にロボット全体の負荷を支える場所に達するまで行われる，通 常のマニピュレータであれば，土台部分，ヒューマノイドロボッ トであれば，足首関節まで探索を行うことになる。

Fig. 5 に 8 自由度を持つシリアルリンクマニピュレータを示 す。これは, ヒューマノイドロボットの胴体 1 自由度 ( $\mathrm{T} 1$ 関 節) +腕 7 自由度（R1 から R4 関節まで）を想定したマニピュ レータである.このマニピュレータを例に，手先から縮退可能 な関節の探索を実際に行った。

手先関節の $\mathrm{z}$ 軸方向から力 : Fz が加えられるとする. 手先の 第一関節（ここでは， R1 関節と呼ぶ）は, $\mathrm{R}$ 型関節であるた め, Table 1 (c) より関節負荷トルクが発生しないことが分かる. また, 次のリンクには, 力 : Fy, Fz およびモーメント力 : $\mathrm{Mx}$ を伝達することが分かる。次の第二関節（P1 関節と呼ぶ）で は, 力: Fy, モーメントカ: Mx は, P1 関節の関節負荷トルク には何の影響もないことが Table 1 (d) から分かる. また，力： $\mathrm{Fz}$ は関節角に依存して負荷トルクを発生させることから，P1 関節は，縮退可能関節の候補となることが分かる．同様に，P1

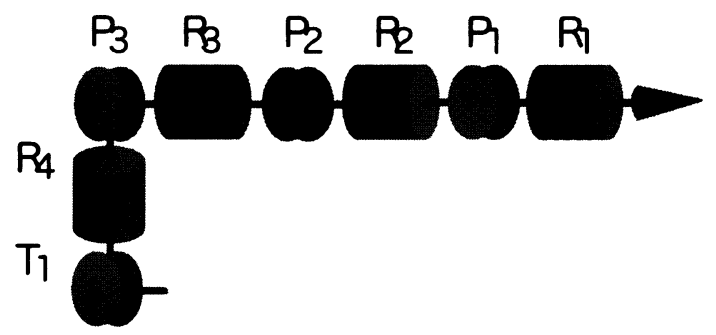

Fig. 5 Serial link manipulator with 8 D.O.F.

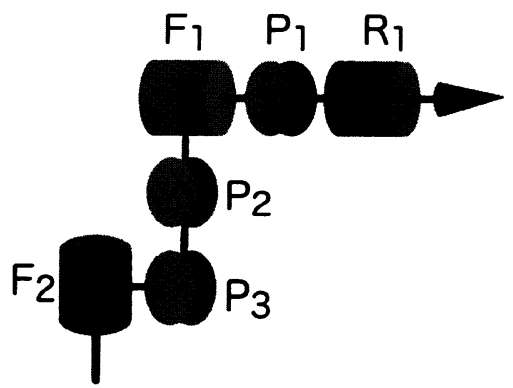

Fig. 6 Serial link manipulator with 6 D.O.F

関節に加わった力 : $\mathrm{Fy}, \mathrm{Fz}$ およびモーメントカ : $\mathrm{Mx}$ が，次の $\mathrm{R}$ 型関節（R2 関節と呼ぶ）にどのように伝達されるかを力伝 達関係の表から調べる.すると，P1 関節が縮退した場合には， 力 $: \mathrm{Fz}$ のみが次の $\mathrm{R} 2$ 関節に伝達されることが分かる。これを 繰り返すことにより，最終的にマニピュレー夕のすべての $\mathrm{P}$ 型 関節が縮退により関節負荷を発生させることなく，手先負荷を 支えることができることが分かる.

同様に, Fig. 6 に示す 6 自由度マニピュレー夕（安川電機社 製 YR-SV3X の関節構成) でも縮退可能関節を探索した。手先 関節の $\mathrm{z}$ 軸方向から力 $: \mathrm{Fz}$ が加えられるとする．手先の第一 関節（R1 関節と呼ぶ）では，次のリンクに力：Fzを伝達する。 次の $\mathrm{P}$ 型関節（P1 関節）では，縮退を利用することができる。 次の $\mathrm{F}$ 型関節（F1 関節と呼ぶ）では， $\mathrm{x}$ 軸方向の力 $: \mathrm{Fx}$ ，モ一 メントカ：My として伝達される，さらに次の $\mathrm{P}$ 型関節 (P2 関 節と呼ぶ）では, 力: $\mathrm{Fy}$, モーメントカ: $\mathrm{Mx}, \mathrm{Mz}$ として伝達 される。このとき，P2 関節では，力：Fyにより関節角依存せ ずに負荷トルクが発生することが分かる．以降同様に繰り返す ことにより，このマニピュレータでは P1 関節のみが縮退を利 用可能であることが分かる。

\section{5. 関節縮退によるアクチュエータの選択的利用を 用いた押し動作}

関節縮退を用いたアクチュエータの選択的利用の有効性を評 価するために，シミュレーションによる評価を行った。シミュ レーションでは, 静的な状態において手先に与えられる外力に より発生する関節負荷トルクの算出を行った. Fig. 7 にシミュ レーションに用いたリンク機構モデルを示す。簡単化のために 平面 3 自由度のリンク機構に胴体を模擬した回転の 1 自由度を 付加した 4 自由度機構とした。 上半身のみのヒューマノイドロ ボットを想定している． 4.4 節で用いた 8 自由度マニピュレータ の手首，肩部等の自由度（R1，R2，R3，P3 関節）を取り除い たもので，今回の作業内容では力学的に等価な機構となる。ま 


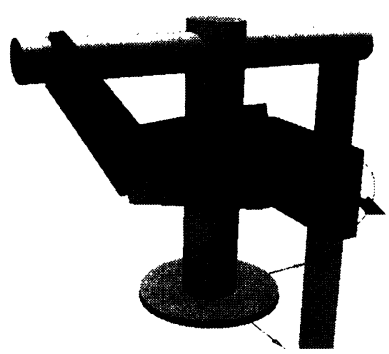

Fig. 7 Upper body of Humanoid robot for simulation

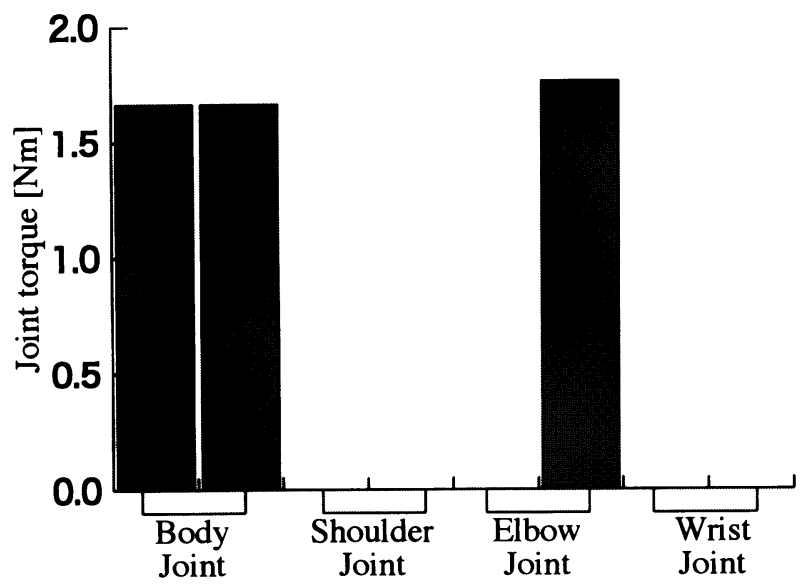

Fig. 8 Comparison of joint torque under singular configuration and non-singular configuration

た, Fig. 7 の機構では, 手首, 时関節が縮退可能関節となる. 重 力の影響は, シミュレーション結果には大きく影響を与えない ため無視した。

Fig. 8 に, 各関節の負荷トルクを棒グラフで示した. 手先に 10 [N] の水平方向の外力が加わったときの, 手首, 时関節を縮退 させた場合と縮退させなかった場合の 2 通りを示してある.リ ンク機構の姿勢は, 手首, 时関節が縮退した状態では, Fig. 1 の ように腕をまっすぐ伸ばした状態になる. 手首, 时関節が縮退状 態ではない姿勢は，手首関節が肩関節と同じ高さになるように， 时関節が $\pi / 2[\mathrm{rad}]$ となるような姿勢を選んだ。なお, Fig. 8 で は，横軸に縮退状態と非縮退状態のそれぞれの関節を表し, 縦 軸に関節負荷トルクを示した。

図より分かるように，関節縮退を行った場合と行わなかった 場合とでは, 胴体部, 手首, 肩関節の負荷トルクには変化はない が, 肘関節に加わる負荷トルクは縮退状態で $0[\mathrm{Nm}]$ となってい る.また，手首関節も縮退状態では，関節負荷トルクが $0[\mathrm{Nm}]$ となっている. ただし, 今回の作業姿勢では, 外力の方向べクト ルと手首関節, 肩関節が一直線上に並んでいるので, 手首, 肩 関節ともに縮退状態でない状態でも負荷トルクが $0[\mathrm{Nm}]$ になっ ている。一方, 胴体部の関節には, どちらの姿勢でも同じ負荷 トルクがかかっている.

以上より, 縮退状態では手先に加わる外力を胴体部の関節で 負担していることが分かる，また，手首，时関節では，手先に 加わる外力の大きさにかかわらず, 縮退状態では負荷トルクは 発生しない.これらのことから,アクチュエータの選択的利用
が可能であることが分かる．本論文では，押し動作を取り上げ たが, 引張力を発生させる場合でも同様の効果が期待できる.

\section{6.おわりに}

本研究では，ヒューマノイドロボットに代表されるような多 自由度ロボットにおいて, 関節縮退を積極的に活用し,アクチュ エー夕を選択的に利用する作業方法を提案した。そして，関節 縮退を用いた作業に有効な関節の導出手法を提案し, 力学シミュ レーションにより関節縮退によりアクチュエータの選択的利用 が可能なことを確認した。

本手法では, 手先には力のみが加わるとし, モーメントカが 加わる場合を想定していない.これは, 通常大きな出力が要求 されるような作業では, レンチ, ハンドル等, モーメントカを 力に変換する道具を用いて行われることが多い. また, 手先の 1 自由度をレンチ等と同様に考えれば, 手先に加わるモーメント 力を力に変換することもできる. そのため, 大きなモーメント 力を手先に要求する作業は少ないと考え, 対象から外した. し かし，モーメントカが加わる場合でも，本手法と同様に縮退を 利用したアクチュエータの選択的利用が可能である. 今後, よ り一般的な拡張を目指してモーメントカも含めた手法を検討し ていきたいと考えている。

また，本手法を有効に活用するためには，さらにロボットの 動作計画, 作業計画にまで踏み込んた手法が必要とされる。そ ういう意味では，まだ未完成の手法ではあるが，ロボットの自 由度の有効活用の方法の一つとして提案したい.

謝 辞 本研究は, 科学研究費補助金「基盤研究 (C): 課題 番号 16500100」の支援を受けて実施された.

\section{参考文 献}

[1] K. Hirai, M. Hirose, Y. Haikawa and T. Takenaka: "The Development of Honda Humanoid Robot," Proc. of the 1998 ICRA, pp.1321-1326, 1998.

[2] K. Nishiwaki, S. Kagami, J.J. Kuffner, M. Inaba and H. Inoue: "Humanoid 'JSK-H7' : Research Platform for Autonomous Behavior and Whole Body Motion," Proceedings of the Third IARP International Workshop on Humanoid and Human Friendly Robotics, pp.2-9, 2002.

[3] K. Kaneko, F. Kanehiro, S. Kajita, K. Yokoyama, K. Akachi, T. Kawasaki, S. Ota and T. Isozumi: "Design of Prototype Humanoid Robotics Platform for HRP," Proc. of IROS 2002, pp.2431-2436, 2002.

[ 4 ] H. Hirukawa, F. Kanehiro, K. Kaneko, S. Kajita, K. Fujiwara, Y. Kawai, F. Tomita, S. Hirai, K. Tanie, T. Isozumi et al.: "Humanoid robotics platforms developed in HRP," Robotics and Autonomous Systems, vol.48, issue 4, pp.165-175, 2004.

[5] 蓮沼仁志, 中嶋勝己, 小林政巳, 御船文里, 宮原啓造, 鷹取正夫, 森 山尚, 家中良太, 横井一仁: “人間型ロボットのための遠隔操縦シス テムの開発一人間型ロボットによる産業車両の代行運転への適用—”, 日本ロボット学会誌, vol.22, no.1, pp.46-54, 2004.

[6] 梶田秀司, 金広文男, 金子健二, 藤原清司, 原田研介, 横井一仁, 比留川博久: “分解運動量制御：運動量と角運動量に基づくヒューマ) イドロボットの全身運動生成”, 日本ロボット学会誌, vol.22, no.6, pp.772-779, 2004.

[7] 梶田秀司, 谷和男: “実時間路面形状計測に基づく動的 2 足歩行の制 御”, 日本ロボット学会誌, vol.14, no.7, pp.1062-1069, 1996.

[8] 古田貴之, 大和秀彰, 永野雅邦, 富山健: “多リンク仮想倒立振子モ一 ドを規範とした二脚移動ロボットの実時間歩容生成法”, 電気学会論 文誌, vol.120-C, no.2, pp.208-214, 2000. 
[9] 山口仁一, 木下昇, 高西淳夫, 加藤一郎: “路面形状に偏差のある環 境に対する適応能力を持つ 2 足歩行ロボットの開発”, 日本ロボット 学会誌, vol.14, no.4, pp.546-559, 1996.

[10] 吉田晴行, 井上健司, 新井健生, 前泰志：“人間型ロボットの作業移 動—作業移動に要求される脚機能の分析—”, 日本ロボット学会誌, vol.19, no.5, pp.660-666, 2001.

[11] 原田研介, 梶田秀司, 金広文男, 藤原清司, 金子健二, 横井一仁, 比留川博久：“ヒューマノイドロボットの脚腕協調に扔ける ZMP 解 析”, 日本ロボット学会誌, vol.22, no.1, pp.28-36, 2004.

[12] A. Ude, C.G. Atkeson and M. Riley: "Programming Full-Body Movements for Humanoid Robots by Observation," Robotics and Autonomous Systems, vol.47, issues 2-3, pp.93-108, 2004.

[13] J. Nakanishi, J. Morimoto, G. Endo, G. Cheng, S. Schaal and M. Kawato: "Learning from demonstration and adaptation of biped locomotion," Robotics and Autonomous Systems, vol.47, issues 2-3, pp.79-91, 2004.

[14] 中村仁彦 他： “関節型ロボットアームの特異点低感度運動分解”, 計 測自動制御学会論文集, vol.20, no.5, pp.453-459, 1984.

[15] Y. Nakamura and H. Hanafusa: "Task Priority Based Redundancy Control of Robot Manipulators," International Journal of Robotics Research, vol.6, no.2, pp.3-15, 1987.

[16] K. Nakai, K. Kosuge and Y. Hirata: "Control of Robot in Singular Configurations for Human-Robot Coordination," Proc. of the 2002 IEEE Int. Workshop on Robot and Human Interactive Communication, pp.356-361, 2002.

[17] K. Nakai, K. Kosuge and Y. Hirata: "Configurations for Human-Robot Coordination," Proc. of the 2002 IEEE Inter- national Workshop on Robot and Human Interactive Communication, pp.356-361, 2002.

[18] K. Yamane and Y. Nakamura: "Dynamic Filter - Concept and Implementation of Online Motion Generator for Human Figures," IEEE Transactions on Robotics and Automation, vol.19, no.3, pp.421-432, 2003.

[19] 杉本浩一: “機構の特異点に関する考察”, 日本ロボット学会誌, vol.11, no. 4 , pp.550-556, 1993.

[20] 杉本浩一：“直列機構の特異点での運動解析”, 日本ロボット学会誌, vol.12, no.4, pp.616-620, 1994.

[21] S. Narasimhan and V. Kumar: "A Second Order Analysis of Manipulator Kinematics in Singular Configurations," 23nd Biennial ASME Mechanisms Conference, ASME Publication Mechanism Synthesis and Analysis, pp.477-484, 1994.

[22] C. Mavroidis and B. Roth: "Method to Determine Uncertain Configurations of $6 \mathrm{R}$ Manipulators," Proc. of the 9th World Congress on the Theory of Machines and Mechanisms (IFToMM), vol.3, pp.1987-1992, 1995.

[23] J.K. Salisbury: "Whole Arm Manipulation," Proc. of the 4th Int. Sympo. Robotics Research, pp.183-189, 1988.

[24] 小金澤鋼一: “壳長自由度を有するマニピュレータの逆運動学の高速かつ 安定な解法”, 日本ロボット学会誌, vol.16, no.5, pp.721-727, 1998.

[25] 望山洋, 示村悦二郎, 小林尚登: “超多自由度シリアルリンクマニピュ レータの制御”, 日本ロボット学会誌, vol.15, no.1, pp.109-117, 1997.

[26] 広瀬茂男, 佐藤幹夫：“多自由度ロボットの干渉駆動”, 日本ロボット 学会誌, vol.7, no.2, pp.128-135, 1989 .

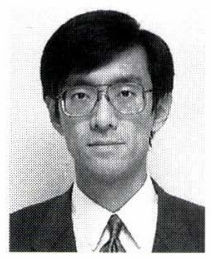

琴坂信哉 (Shinya Kotosaka)

1963 年 7 月 18 日生. 1996 年埼玉大学大学院博士 (工学) 取得, 理化学研究所奨励研究員, (株) ATR 人間情報通信研究所滞在研究員, 科学技術振興事業 団川人学習動態脳プロジェクト研究員を経て, 現在, 埼玉大学大学院理工学研究科人間支援・生産科学部 門所属. 日本機械学会会員.

（日本ロボット学会正会員）

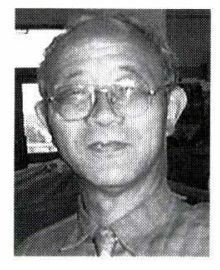

大滝英征 (Hideyuki Ohtaki)

1943 年 9 月 27 日生. 1972 年東京大学大学院工学 研究科博士課程修了, 同年, 工業技術院機械技術研 究所入所. 1983 年埼玉大学工学部助教授, 1987 年 同大学教授. 現在, 埼玉大学大学院理工学研究科人 間支援·生産科学部門所属. 工学博士. 日本機械学 会会員. 